\title{
DISKRIMINASI DALAM PENGADAAN JASA PEMBUATAN LOGO BARU PT. PERTAMINA (PERSERO)
}

\author{
Oleh
}

\author{
Deni Aulia Ahmad*
}

\begin{abstract}
Abstrak
Proses penunjukan langsung PT. PERTAMINA kepada LANDOR dalam kasus pengadaan jasa pembuatan logo baru PT. PERTAMINA (Persero) bersifat diskriminasi karena PT. PERTAMINA (Persero) menunjuk LANDOR sebagai pengembang tunggal dari proyek pembuatan logo baru PT. PERTAMINA (Persero) tanpa melalui proses lelang tender serta tidak menghiraukan sama sekali penawaran yang diajukan oleh perusahaan- perusahaan lainnya yang sebagai pesaing dari LANDOR. Praktek diskriminasi yang dilakukan PT. PERTAMINA (Persero) menyebabkan penguasaan pasar dan melanggar Pasal 19 hurufd Undang-Undang Nomor 5 Tahun 1999 yang di atur secara Rule of reason. Diskriminasi yang dilakukan PT. PERTAMINA (Persero) menimbulkan dampak negatif bagi persaingan di bidang jasa pembuatan Logo.
\end{abstract}

Kata Kunci : diskriminasi, tender

\section{PENDAHULUAN}

Negara-negara di dunia termasuk Indonesia pada akhir abad duapuluh mulai meningkatkan peran pemerintah dalam mengatur monopoli ${ }^{1}$. Praktek monopoli dilarang karena dapat menghambat persaingan usaha yang sehat. Lahirnya Undang-Undang Nomor 5 Tahun 1999 merupakan tuntutan nasional, jika ditinjau dari sisi kehidupan nasional jelas bahwa basis kultural (asas kekeluargaan) dan konstitusional (demokrasi ekonomi) kita

\footnotetext{
*Haryanto \& Partners Law Firm, deni1210@yahoo. co.id

Paul A. Samuelson dan William D. Nordhaus, Ilmu Makro Ekonomi, Media Global Edukasi, Jakarta, 2004, h. 27.
}

memang sama sekali menolak praktekpraktek monopolistik dalam kehidupan ekonomi yang merugikan rakyat. $^{2}$ Lahirnya Undang-Undang Nomor 5 Tahun 1999 juga dipengaruhi oleh munculnya fenomena globalisasi ekonomi yang mengandung makna semakin meningkatnya ketergantungan antarbangsa di berbagai bidang kehidupan khususnya bidang ekonomi, mengharuskan berbagai bangsa termasuk Indonesia menaati rambu-rambu (peraturan) baku dalam bisnis antarbangsa, sebagai konsekuensi masuknya Indonesia dalam organisasi perdagangan dunia seperti

\footnotetext{
2 Rachmadi Usman, Hukum Persaingan Usaha di Indonesia, Gramedia Pustaka Utama, Jakarta, 2004, h. 4.
} 
WTO, APEC, AFTA, NAFTA, dan lain sebagainya.

Praktek monopoli sudah merupakan kenyataan yang tidak dapat dihindarkan karena merupakan akibat atas pemilihan sistem-sistem ekonomi yang ada. Bentuk monopoli yang pertama dapat terjadi karena memang dikehendaki oleh hukum, sehingga timbulah apa yang disebut sebagai monopoly by law. UUD 1945 Pasal 33 juga membenarkan adanya monopoli jenis ini, yaitu dengan memberi monopoli bagi negara untuk menguasai bumi dan air dan kekayaan alam yang terkandung didalamnya serta cabang-cabang produksi yang menguasai hajat hidup orang banyak. ${ }^{3}$

Bentuk monopoli yang kedua adalah monopoly by nature, yaitu monopoli yang lahir dan tumbuh secara alamiah karena didukung oleh iklim dan lingkungan yang cocok. Kita dapat melihat bentuk monopoli seperti ini yaitu tumbuhnya perusahaanperusahaanyangkarenamemilikikeunggulan dan kekuatan pasar tertentu dapat menjadi raksasa bisnis yang menguasai seluruh pangsa pasar yang ada, mereka menjadi besar karena sesuai dengan tempat di mana mereka tumbuh, selain itu karena berasal dan didukung modal dasar yang besar dan SDM berupa tenaga kerja yang baik, serta memiliki faktor-faktor yang dominan. ${ }^{4}$ Bentuk monopoli yang kedua ini dalam literatur yang lain dinamakan "pure monopoly" atau monopoli murni atau dinamakan juga "natural monopoly", dan

${ }^{3}$ Ahmad Yani dan Gunawan Widjaja, op. cit, h. 5.

${ }^{4}$ Ibid. ini tidak dilarang. ${ }^{5}$

Bentuk monopoli yang ketiga adalah monopoly by licence. Monopoli ini diperoleh melalui lisensi dengan menggunakan mekanisme kekuasaan. Monopoli jenis ini yang sering menimbulkan distorsi ekonomi karena kehadirannya mengganggu keseimbangan (equilibrium) pasar yang sedang berjalan dan bergeser kearah yang diingini oleh pihak yang memiliki monopoli tersebut. ${ }^{6}$

Di Indonesia dan banyak negara lain, berbagai sektor yang bersifat monopoli alamiah dan terkait dengan kepentingan publik, diatur oleh negara yang diwakili oleh lembaga-lembaga negara tertentu. Permasalahan kemudian muncul, yaitu saat negara sebagai pemegang hak tunggal menyerahkan kewenangannya untuk mengelola berbagai sektor tersebut kepada pelaku usaha. Penyerahan kewenangan dan hak pengelolaan mempunyai implikasi ekonomi dan bisnis berupa pendapatan dan laba yang selalu menjadi incaran para pelaku usaha. Mereka akan bersaing untuk memperoleh hak monopoli alamiah ini. ${ }^{7}$ Peran monopoli alamiah seharusnya diminimalisir dengan memunculkan peran hukum untuk menghilangkan distorsi ekonomi sebagai akibat persaingan usaha tidak sehat, dengan demikian kita dapat mencermati dan menata kembali dunia usaha di Indonesia agar dapat tumbuh serta berkembang secara sehat dan benar,

\footnotetext{
${ }^{5}$ Asril Sitompul, Praktek Monopoli dan Persaingan Usaha Tidak Sehat, Citra Aditya Bakti, Bandung, 1999, h. 10.

${ }^{6}$ Ahmad Yani dan Gunawan Widjaja, op.cit., h. 6.

7 Ibid.
} 
sehingga dapat menghindarkan pemusatan kekuatan ekonomi pada perorangan dan kelompok tertentu dan pada akhirnya tercipta persaingan usaha yang sehat. ${ }^{8}$

Pelaku usaha selalu mencoba mengambil keuntungan yang sebesarbesarnya, keuntungan yang paling besar bagi pelaku usaha adalah jika dapat menguasai pasar dan menentukan apa yang harus terjadi pada pasar tersebut. Pelaku usaha sering jika melakukan hal-hal yang mencoba untuk menghambat pelaku usaha lain untuk masuk ke dalam pasar ( barrier to entry ). Inilah yang mendasari pendekatan perilaku, bahwa pada dasarnya perilaku yang merugikan usaha bukan hanya dapat dilakukan oleh pelaku usaha yang besar tapi juga dapat dilakukan semua pelaku usaha. ${ }^{9}$

Salah satu tindakan (perilaku) yang dapat atau biasa dilakukan pelaku usaha untuk menciptakan hambatan untuk masuk kedalam pasar adalah persekongkolan atau konspirasi usaha, yang artinya sebagaimana disebutkan dalam UndangUndang Nomor 5 Tahun 1999 pasal 1 angka 8 "Persekongkolan atau konspirasi usaha adalah bentuk kerjasama yang dilakukan oleh pelaku usaha dengan pelaku usaha lain dengan maksud untuk menguasai pasar bersangkutan bagi kepentingan pelaku usaha yang bersekongkol."

Salah satu wujud dari persekongkolan tersebut dapat berupa diskriminasi terhadap pelaku usaha lain. Preaktek diskriminasi tersebut merupakan tindakan yang dilarang

${ }^{8}$ Ahmad Yani dan Gunawan Widjaja, op.cit., h.8.

9 Partnership for Business Competition (PBC), Persaingan Usaha dan Hukum yang Mengaturnya di Indonesia, Elips, 2000, h.39. dalam Undang-Undang Nomor 5 Tahun 1999, sebagaimana disebutkan dalam pasal 19 huruf (d) "Pelaku usaha dilarang melakukan satu atau beberapa kegiatan, baik sendiri maupun bersama pelaku usaha lain, yang dapat mengakibatkan terjadinya praktek monopoli dan atau persaingan usaha tidak sehat berupa: melakukan praktek diskriminasi terhadap pelaku usaha tertentu. "

Contoh diskriminasi terhadap pelaku usaha adalah dalam kasus pengadaan jasa pembuatan logo baru PT. PERTAMINA (Persero) yang terkesan terdapat persekongkolan dengan modus penunjukan langsung oleh PT. PERTAMINA (Persero) kepada LANDOR dengan tidak menghiraukan tawaran dari penyedia jasa lainnya. Adapun rumusan masalah yang dapat ditarik dalam kasus tersebut antara lain : apakah PT. PERTAMINA terbukti melanggar ketentuan pasal 19 huruf (d) Undang-Undang Nomor 5 Tahun 1999?; pendekatan yuridis apa yang digunakan oleh KPPU dalam memutus perkara pengadaan jasa pembuatan logo Pertamina?

DISKRIMINASI YANG DILAKUKAN PT. PERTAMINA (PERSERO) DALAM PENGADAAN JASA PEMBUATAN LOGO BARU

Diskriminasi Mengakibatkan Terjadinya Praktek Monopoli dan atau Persaingan Usaha Tidak Sehat

Undang-undang Nomor 5 Tahun 1999 pada dasarnya melarang perbuatan anti persaingan dan perjanjian-perjanjian yang 
yang mengandung klausula anti persaingan. Perbuatan-perbuatan anti persaingan berupa monopoli, praktek-praktek bisnis restriktif, persekokongkolan diantara pesaing, praktekpraktek bisnis tidak jujur, dan perangkapan jabatan diberbagai perusahaan. ${ }^{10}$ Undang-Undang Nomor 5 Tahun 1999 juga melarang adanya perjanjian dan perbuatan yang bersifat anti persaingan, dan juga melarang adanya penyalahgunaan posisi dominan dari pelaku usaha. ${ }^{11}$

Salah satu kegiatan yang dilarang oleh Undang-Undang Nomor 5 Tahun 1999 adalah praktek diskriminasi tehadap pelaku usaha. Larangan praktek diskriminasi ini diatur dalam Undang-Undang Nomor 5 Tahun 1999 pasal 19 huruf (d), sebagaimana disebutkan bahwa "Pelaku usaha dilarang melakukan satu atau beberapa kegiatan, baik sendiri maupun bersama pelaku usaha lain, yang dapat mengakibatkan terjadinya praktek monopoli dan atau persaingan usaha tidak sehat berupa melakukan praktek diskriminasi terhadap pelaku usaha tertentu. ,

Diskriminasi terhadap pelaku usaha dilarang karena dapat mengakibatkan terjadinya praktik monopoli dan atau persaingan usaha tidak sehat.

Pasal 1 angka 1 Undang-Undang Nomor 5 Tahun 1999 memberikan pengertian secara umum terhadap istilah monopoli, yang dimaksud dengan monopoli adalah penguasaan atas produksi dan atau pemasaran barang dan atau jasa atas penggunaan jasa tertentu oleh satu pelaku

\footnotetext{
10 Ibid, h. 512.

11 Ibid, h. 525.
}

usaha atau satu kelompok usaha. ${ }^{12}$

Praktek diskriminasi terhadap pelaku usaha tertentu dapat terlihat dalam kasus pelaksanaan pengadaan jasa pembuatan logo baru PT. PERTAMINA (Persero), dalam kasus pengadaan jasa pembuatan logo tersebut pihak PT. PERTAMINA (Persero) melakukan penunju kan langsung kepada LANDOR tanpa melalui proses lelang tender. Kebijakan penunjukan langsung tersebut telah mendiskriminasikan pelaku usaha lain dengan memperlakukan LANDOR secara istimewa, tanpa menghiraukan penawaran yang telah diajukan oleh perusahaan jasa konsultankomunikasi(branding Consultant) lainnya, sehingga tindakan tersebut benarbenar menutup persaingan usaha pada pasar jasa konsultan komunikasi, dan berikutnya akan menimbulkan berbagai dampak negatif sebagai konsekuensi atas terciptanya pasar yang tidak sehat. Dampak negatif tersebut dapat dijelaskan oleh penulis, yaitu antara lain : menyebabkan halangan bagi pelaku usaha lain untuk memasuki pasar (barrier to entry, dan kerugian bagi PT. PERTAMINA (Persero) sendiri yaitu biaya yang tinggi dalam pengadaan jasa pembuatan logo baru tersebut.

\section{Diskriminasi mengakibatkan halangan bagi pelaku usaha lain untuk memasuki pasar ( barier to entry)}

Suatu pasar dapat dikatakan mengalami barrier to entry jika para pelaku usaha tidak memiliki kesempatan yang sama dengan para pelaku usaha yang sejenis untuk masuk

\footnotetext{
${ }^{12}$ Pasal 1 angka 1 Undang-Undang Nomor 5 Tahun 1999.
} 
dalam pasar yang bersangkutan. Pasar yang mempunyai barrierto entryakan menjadikan pasar tersebut sebagai pasar yang tertutup untuk pelaku usaha lain. Pelaku usaha lain yang ingin memasuki pasar tersebut akan membutuhkan biaya yang cukup besar, tentu saja hal ini berdampak inefisiensi pada pelaku usaha tersebut.

Tindakan PT. PERTAMINA (Persero) dengan melakukan penunjukan langsung kepada LANDOR dapat mematikan persaingan antar pelaku usaha, perusahaan branding consultant pesaing dari LANDOR yang sebenarnya memiliki kemampuan untuk mengembangkan usahanya di bidang penyediaan jasa pembuatan logo dan strategi pengembangannya, akan mengalami hambatan bahkan kehilangan kesempatan untuk bersaing dan memasuki pasar pengadaan jasa pembuatan logo baru PT. PERTAMINA (Persero), karena PT. PERTAMINA (Persero) lebih memberikan informasinya dan kepercayaannya kepada LANDOR perusahaan branding consultant yang akan dipilih sebagai penyelenggara pengadaan logo baru, dan juga PT. PERTAMINA (Persero) mengabaikan tawaran yang diajukan oleh perusahaan branding consultant pesaing LANDOR lainnya

\section{Diskriminasi mengakibatkan kerugian bagi PT. PERTAMINA (Persero)}

Praktek diskriminasi yang dilakukan oleh PT. PERTAMINA (Persero) akan menciptakan suatu kondisi pasar monopoli, dalam kondisi ini pelaku usaha monopoli yaitu LANDOR akan bertindak seenaknya, karena dalam pasar monopoli produsen akan berada pada posisi yang sangat dibutuhkan oleh konsumen sehingga apapun yang ditawarkan oleh produsen lebih banyak akan diterima oleh PT. PERTAMINA (Persero) selaku pihak konsumen. Dengan kondisi seperti ini LANDOR tidak akan berusaha lebih untuk melakukan efisiensi-efisiensi yang seharusnya dapat dilakukan, dengan melakukan efisiensi maka biaya-biaya yang timbul dapat ditekan dan pada akhirnya harga produksi akan lebih murah.

Kondisipasarpengadaanjasapembuatan logo baru PT. PERTAMINA (Persero) yang terbentuk akibat praktek diskriminasi yang dilakukan PT. PERTAMINA (Persero) akan memunculkan LANDOR sebagai satusatunya calon penyedia jasa pembuatan, dengan kondisi seperti ini maka LANDOR sudah pasti tidak akan bersusah payah untuk menggali seluruh potensi yang dimiliki untuk meningkatkan kinerja dan menekan jumlah biaya produksi. dampak dari semua itu pada akhirnya akan dibebankan kepada PT. PERTAMINA (Persero) sebagai konsumen, sehingga menghilangkan kesempatan PT. PERTAMINA (Persero) sendiri untuk mendapatkan harga yang lebih murah, dan kwalitas yang lebih bagus, dengan kata lain PT. PERTAMINA (Persero) sudah pasti membayar harga yang tinggi dengan kwalitas yang belum tentu paling bagus.

\section{Unsur-Unsur Diskriminasi dalam Pengadan Jasa Pembuatan Logo Baru PT. PERTAMINA (Persero)}

Ketentuan Pasal 19 huruf d Undangundang Nomor 5 Tahun 1999 menyatakan 
"Pelaku usaha dilarang melakukan satu atau beberapa kegiatan, baik sendiri maupun bersama pelaku usaha lain, yang dapat mengakibatkan terjadinya praktek monopoli dan atau persaingan usaha tidak sehat berupa: melakukan praktek diskriminasi terhadap pelaku usaha tertentu"

Mengacu pada bunyi pasal tersebut maka, dapat dijabarkan bahwa Pasal 19 huruf d Undang-undang Nomor 5 Tahun 1999 mengandung unsur-unsur sebagai berikut:

\section{Pelaku usaha}

Pelaku usaha yang dimaksud disini adalah PT. PERTAMINA (Persero) selaku badan usaha yang melakukan kegiatan usaha di bidang perminyakan yang dalam perkara ini melakukan kegiatan pengadaan jasa pembuatan logo untuk perubahan logonya. 13

Melakukan diskriminasi terhadap pelaku usaha tertentu

Diskriminasi adalah tindakan, sikap dan perlakuan yang berbeda terhadap pelaku usaha tertentu untuk mendapatkan kesempatan yang sama dengan pelaku usaha lain pada pasar bersangkutan yang sama. Tindakan PT. PERTAMINA (Persero) dapat dikategorikan sebagai tindakan diskriminasi karena PT. PERTAMINA (Persero) telah mengistimewakan LANDOR dan tidak memberikan kesempatan kepada perusahaan pembuat logo lain untuk mendapatkan pekerjaan pembuatan logo PT. PERTAMINA (Persero). ${ }^{14}$

\footnotetext{
13 Salinan Putusan KPPU, op.cit., h. 18.

14 Ibid.
}

Berkaitan dengan alasan PT. PERTAMINA (Persero) menunjuk langsung LANDOR karena reputasi,kompetensi dan pengalaman, alasan tersebut tidak dapat dijadikan sebagai pembenar karena berdasarkan hasil pemeriksaan terdapat pelaku usaha lain yang memiliki reputasi, kompetensi dan pengalaman yang setingkat dengan LANDOR. ${ }^{15}$

\section{Persaingan usaha tidak sehat}

Berdasarkan ketentuan Pasal 1 angka 6 Undang-undang Nomor 5 Tahun 1999, persaingan usaha tidak sehat adalah "persaingan antar pelaku usaha dalam menjalankan kegiatan produksi dan atau pemasaran barang dan atau jasa yang dilakukan dengan cara tidak jujur atau melawan hukum atau menghambat persaingan usaha."

Tindakan PT. PERTAMINA (Persero) menunjuk langsung LANDOR melanggar ketentuan BAB VII SK 036 karena LANDOR bukan konsultan komunikasi. Tindakan PT. PERTAMINA (Persero) yang menunjuk langsung LANDOR sebagai pelaksana pembuatan logo merupakan tindakan menghambat persaingan karena menutup kesempatan perusahaan pembuatan logo lain untuk memberikan jasa pembuatan logo PT. PERTAMINA (Persero), dengan demikian, maka tindakan penunjukan langsung LANDOR oleh PT. PERTAMINA (Persero) adalah tindakan persaingan usaha tidak sehat. ${ }^{16}$

\footnotetext{
${ }^{15}$ Ibid.

${ }^{16}$ Ibid, h. 19.
} 
Pengecualian Monopoli oleh PT. PERTAMINA (Persero) sebagai BUMN (Badan Usaha Milik Negara)

Ada suatu bentuk monopoli yang dapat terjadi karena memang dikehendaki oleh hukum, sehingga timbulah apa yang disebut sebagai monopoly by law. UUD 1945 Pasal 33 juga membenarkan adanya monopoli jenis ini, yaitu dengan memberi monopoli bagi negara untuk menguasai bumi dan air dan kekayaan alam yang terkandung didalamnya serta cabang-cabang produksi yang menguasai hajat hidup orang banyak. ${ }^{17}$

Pengecualian Monopoli oleh BUMN ini diatur dalam pasal 51 Undang-Undang Nomor 5 Tahun 1999, sebagaimana disebutkan bahwa :

" monopoli dan atau pemusatan kegiatan yang berkaitan dengan produksi dan atau jasa yang menguasai hajat hidup orang banyak serta cabang-cabang produksi yang peting bagi negara diatur dengan undang-undang dan diselenggarakan oleh Badan Usaha Milik Negara dan atau badan atau lembaga yang dibentuk atau ditunjuk oleh pemerintah."

Pasal 51 Undang-Undang Nomor 5 Tahun 1999 memberikan dasar hukum bagi monopoli negara dan swasta, tapi tidak ada maksud untuk menghapuskan larangan monopoli. Tujuan uatama pasal tersebut adalah untuk melakukan pengawasan demokratis terhadap monopoli. Monopoli tersebut hanya dapat terlaksana sebatas

\footnotetext{
${ }^{17}$ Ahmad Yani dan Gunawan Widjaja, Seri Hukum Bisnis Anti Monopoli, RajaGrafindo Persada, Jakarta, 1999, h. 5.
}

kriteria-kriteria yang termuat dalam pasal 51, yang merupakan ukuran bagi legitimasi ekonomi, yaitu : Hanya monopoli negara yang memuaskan permintaan mayoritas masyarakat dengan barang atau jasa atau mewakili cabang produksi yang penting bagi kepentingan negaralah yang sah. ${ }^{18}$

PT. PERTAMINA (Persero) sebagai BUMN (Badan Usaha Milik Negara) ditunjuk oleh pemerintah sebagai pelaksana kegiatan ekonomi dibidang perminyakan dan gas, mulai dari eksplorasi, eksploitasi, pengolahan, sampai dengan pemasaran. Kegiatan monopoli oleh PT. PERTAMINA (Persero) dibenarkan karena terkait dengan monopoli atas minyak. Minyak di Indonesia diakui sebagai kekayaan alam yang menguasai hajad hidup orang banyak, mengingat ketergantungan yang sangat kuat masyarakat Indonesia terhadap minyak mulai dari perorangan, rumah tangga sampai industri. Inilah yang dimaksud sebagai batasan monopoli yang diperbolehkan kepada PT. PERTAMINA (Persero) oleh Undang-undang. Tindakan Diskriminasi yang dilakukan oleh PT. PERTAMINA (Persero) dengan menunjuk langsung LANDOR tidak termasuk dalam batasan tindakan monopoli yang diperbolehkan.

\footnotetext{
${ }^{18}$ Knud Hansen, et al., Kebijakan Persaingan dan UU Antimonopoli Dalam Ekonomi Pasar : UU Larangan Monopoli dan Persaingan Usaha tidak Sehat, Katalis, Jakarta, 2001, h. 481-482.
} 


\section{METODE PENDEKATAN}

YANG DIGUNAKAN UNTUK

MENDETEKSI DAN MENGANALISIS

DISKRIMINASI

\section{Pendekatan Dalam Hukum Persaingan}

\section{Usaha}

Agar dalam dunia bisnis timbul iklim persaingan yang sehat maka diperlukan adanya pendekatan-pendekatan dalam menegakan hukum persaingan usaha, sebab dunia usaha atau bisnis merupakan bidang yang sangat sensitif terhadap intervensi legalisasi.Untuk itu ada beberapa pendekatan masalah yang dapat dilakukan terkait dengan masalah persaingan usaha, pendekatan masalah tersebut meliputi:

\section{Pendekatan ekonomi}

Pendekatan ekonomi ditujukan untuk mengetahui kondisi yang sebenarnya apakah dalam suatu pasar terdapat atau tidak adanya persaingan. Peran penting pasar dalam hukum persaingan dijelaskan oleh Knudd Hansen dengan menekankan terwujudnya pasar yang berfungsi sebagai prasyarat pertamayangharusdipenuhidalamkebijakan ekonomi nasional, selain mekanisme harga agar persaingan dapat berlangsung. ${ }^{19}$ Lebih lanjut, pasar bukan hanya merupakan arena dimana kegiatan ekonomi sekaligus persaingan berlangsung, melainkan juga menjadi salah satu kriteria untuk mengukur tingkat persaingan. Oleh karena persaingan terjadi di pasar maka dugaan atas adanya pelanggaran terhadap persaingan harus

\footnotetext{
19 Sih Yuliana Wahyuningtyas, "Urgensi PengaturanTentang Pasar Bersangkutan Dalam Hukum Persaingan Usaha Di Indonesia”, Jurnal Hukum Bisnis, Volume 24, No 2, 2005, h.22.
}

dianalisis berdasarkan kondisi pasar dimana pelanggaran yang diduga muncul tersebut terjadi. $^{20}$

Salah satu indikator yang dijadikan pedoman untuk menentukan ada atau tidaknya persaingan adalah dengan melihat struktur pasar. Perlunya struktur pasar dalam perekonomian diketahui oleh pelaku usaha karena dengan struktur pasar akan dapat diketahui atau dapat digambarkan seberapa besar tingkat persaingan disuatu pasar, baik terhadap barang maupun terhadap jasa tertentu. ${ }^{21}$

Untuk dapat melihat dampak struktur pasar tehadap kondisi dan iklim persaingan usaha didalamnya, maka terdapat dua perbandingan antara dua model pasar yang berlawanan secara ekstrim yaitu model persaingan sempurna dan model persaingan tidak sempurna.

Dari beberapa penjelasan mengenai ciri-ciri dan bentuk-bentuk struktur pasar tersebut dapat diketehui kapan kondisi suatu pasar terdapat persaingan yang wajar diantara pelaku usaha. Ukuran kunci apakah sebuah pasar dapat dikatakan persaingan sempurna atau tidak adalah kemampuan penjual untuk mempengaruhi pasar atau menentukan harga. Walaupun ada 200 penjual atau bahkan lebih didalam pasar, tetapi apabila dalam pasar tersebut ada satu atau dua penjual yang mempengaruhi pasar, maka pasar tersebut tidak dapat dikatakan pasar persaingan sempurna. ${ }^{22}$

\footnotetext{
${ }^{20}$ Ibid.

${ }^{21}$ Bahan Kuliah Hukum Persaingan Usaha Oleh L. Budi Kagramanto.

${ }^{22}$ ELIPS, Persaingan Usaha dan Hukum Yang Mengaturnya di Indonesia, 2000, h. 11. (Selanjudnya disebut ELIPS II)
} 


\section{Pendekatan yuridis}

Untuk menentukan suatu perbuatan yang dilakukan oleh seorang pelaku usaha dapat atau tidak menimbulkan persaingan usaha tidak sehat, selain dengan mengunakan pendekatan ekonomi juga dapat dilakukan dengan menggunakan pendekatan yuridis berdasarkan substansi yang ada dalam ketentuan Undang-Undang Nomor 5 Tahun 1999 tentang Latangan Praktek Monopoli dan Persaingan Usaha Tidak Sehat.

Selama ini dikenal 2 (dua) macam prinsip hukum yang dapat digunakan sebagai dasar pengaturan Antimonopoli dan persaingan usaha. Pertama adalah per se illegal (per se illegal approach) dan yang kedua adalah rule of reason (rule of reason approach). Kedua macam prinsip hukum dalam persaingan usaha ini dapat diterapkan untuk menghukum pelaku usaha yang diduga telah melakukan pelanggaran terhadap ketentuan-ketentuan dalam Undang-Undang Nomor 5 Tahun 1999. ${ }^{23}$

Pendekatan Per Se Illegal menyatakan setiap perjanjian atau kegiatan usaha tertentu ilegal, tanpa pembuktian lebih lanjut atas dampak yang ditimbulkan oleh perjanjian atau kegiatan usaha tersebut. ${ }^{24}$

Prinsip hukum per se illegal, antara lain dirumuskan oleh Kaplan, yakni bahwa "hambatan perdagangan dianggap melakukan per se illegal jika secara inheren bersifat anti kompetitif, tidak ada

\footnotetext{
${ }^{23}$ L. Budi Kagramanto, "Prinsip Per Se Ilegal dan Rule of Reason Dalam Hukum Persaingan Usaha", Yuridika, Vol. 19, Maret-April 2004, h. 105.

${ }^{24}$ A.M. Tri Anggraini, "Penerapan Pendekatan Rule of Reason dan Per Se Ilegal dalam Hukum Persaingan", Jurnal Hukum Bisnis, Volume 24, No 2, 2005, h. 5.
}

keuntungan yang dapat diraih darinya, dan tidak ada maksud lain selain menghalangi atau melumpuhkan persaingan. ${ }^{25}$ Oleh karaena itu, pada prinsipnya terdapat dua syarat dalam melakukan pendekatan per se illegal, yakni pertama, harus ditujukan lebih kepada "perilaku bisnis" dari pada situasi pasar, kerena keputusan melawan hukum dijatuhkan tanpa disertai lebih lanjut, misalnya menghendaki akibat yang melingkupinya. Metode pendekatan seperti ini dianggap fair, jika perbuatan ilegal tersebut merupakan "tindakan sengaja" oleh perusahaan yang seharusnya dapat dihindari. Kedua, adanya identifikasi secara tepat atau mudah mengenai jenis praktek atau batasan perilaku yang terlarang. Dengan perkataan lain, penilaian atas tindakan dari pelaku usaha, baik dipasar maupun dalam proses pengadilan harus dapat ditentukan dengan mudah. Meskipun demikian, diakui bahwa terdapat perilaku yang terletak dalam batas-batas yang tidak jelas antara perilaku terlarang dan perilaku yang sah. ${ }^{26}$

Ditambahkan pula bahwa jika suatu hambatan termasuk dalam kategori per se illegal, ketidak patutan dan juga ketidak adilan dari hambatan (perdagangan) tersebut telah secara konklusif diasumsikan, tanpa disyaratkan adanya pembuktian. ${ }^{27}$

Selain menggunakan pendekatan per se illegal, dalam pendekatan yuridis hukum persaingan usaha juga dikenal adanya pendekatan secara rule of reason. Rule of reason adalah suatu pendekatan untuk mengevaluasi akibat perjanjian atau kegiatan

\footnotetext{
${ }^{25}$ ELIPS II, op.cit., h. 63.

${ }^{26}$ A.M. Tri Anggraini, op.cit., h.7.

${ }^{27}$ ELIPS II, loc.cit.
} 
usaha tertentu, guna menentukan apakah suatuperjanjianataukegiatantersebutbersifat menghambat atau mendukung persaingan. ${ }^{28}$ Ruleofreason(ruleofreasonapproach)dalam persaingan usaha merupakan kebalikan dan lebih luas cakupannya dibandingkan dengan per se illegal (per se illegal approach.). ${ }^{29}$

Pendekatan rule of reason diterapkan terhadap tindakan-tindakan yang tidak bisa secara mudah dilihat ilegalitasnya tanpa menganalisis akibat tindakan itu terhadap kondisi persaingan. Dalam pendekatan rule of reason pengadilan disyaratkan untuk mempertimbangkan faktor-faktor seperti latar belakang dilakukannya tindakan, alasan bisnis di balik tindakan itu, serta posisi si pelaku tindakan dalam industri tertentu. ${ }^{30}$

Sehingga untuk mengatakan bahwa suatu perbuatan yang telah dituduhkan melanggar ketentuan dalam UndangUndang Nomor 5 Tahun 1999 pencari fakta harus mempertimbangkan dan menganalisa keadaan disekitar kasus untuk menentukan apakah perbuatan tersebut membatasi persaingan usaha secara tidak patut.

Dalam perkembangannya pendekatan rule of reason dapat dibedakan lagi menjadi dua yaitu, rule of reason yang agak keras atau mendekati per se illegal dan rule of reason yang lunak atau harus benar-benar dibuktikan semua unsurnya. ${ }^{31}$ Dalam metode rule of reason, ada dua teori pembuktian yang biasa dipakai oleh Komisi Pengawas Persaingan Usaha dalam mengevaluasi tindakan yang

\footnotetext{
28 Ibid., h.5.

${ }^{29}$ L. Budi Kagramanto, op.cit., h.109.

30 Arie Siswanto, op.cit, h.67.

31 Bahan Kuliah Hukum Persaingan Usaha oleh Sinar Ayu Wulandari.
}

dilakukan oleh pelaku usaha, yaitu ${ }^{32}$ : Bright Line Evidence Theory dan Hard Line Evidence Theory.

Masing-masing pola pendekatan tersebut mengandung keunggulan dan kelemahan. Keunggulan rule of reason adalah,menggunakan analisisekonomiuntuk mencapai efisiensi guna mengetahui dengan pasti,yaituapakahsuatutindakanpelakuusaha memiliki implikasi kepada persaingan. ${ }^{33}$ Pendekatan rule of reason mengandung juga kelemahan. Suatu perjanjian yang berakibat anti persaingan biasanya masih dianggap sah berdasarkan rule of reason, bukan karena perjanjian tersebut secara wajar dianggap sah, namun karena adanya beban pembuktian yang berat dan biaya mahal yang harus ditanggung oleh penggugat. ${ }^{34}$ Kelemahan lainya dari rule of reason, dan mungkin kelemahan yang paling utama adalah, bahwa rule of reason mensyaratkan pengetahuan teori ekonomi dan sejumlah data ekonomi yang kompleks, dimana mereka belum tentu memiliki kemampuan yang cukup untuk memahaminya guna dapat menghasilkan keputusan yang rasional. Adanya kekurang mampuan dalam memahmi data dan teori ekonomi, mengakibatkan serangkaian keputusan yang kurang tepat dan tidak konsisten.

Sebaliknya, pendekatan per se lilegal tidakmemerlukanpengetahuanteoriekonomi dan pengumpulan data bisnis. Hakim

\footnotetext{
32 Ahmad Junaidi, Komisi Pengawas Persaingan Usaha Daerah, Surabaya, 23 Juli 2007.

${ }_{33}$ Tri Anggraini, A.M., Larangan Praktek Monopoli dan Persaingan Tidak Sehat, cet. I, Program Pasca Sarjana. Fakultas Hukum Universitas Indonesia, Jakarta, 2003, h. 126.

${ }^{34}$ Ibid., h. 139.
} 
hanya membuktikan, apakah perjanjian tersebut mempengaruhi persaingan, yaitu apakah perjanjian tersebut mendorong atau menghambat persaingan. Dengan demikian, biaya prosedur menjadi murah dan cepat. ${ }^{35}$ Selain itu pendekatan per se illegal memiliki keunggulan yaitu adanya kepastian usaha, efisiensi dalam proses litigasi, dan sebagai alat untuk mencegah dampak persaingan, kerena tindakan yang melanggar ketentuan dalam Undang-Undang Nomor 5 Tahun 1999 jelas-jelas melanggar hukum persaingan.

Namun demikian, pendekatan per se illegal mengandung kelemahan pula, karena biasanya selalu beranggapan, akan menghukum setiap perjanjian atau tindakan yang bersifat menghambat perdagangan. Tidak semua perjanjian diantara pesaing merugikan persaingan, karena banyak kegiatan bersama yang mendatangkan manfaat secara kompetitif. ${ }^{36}$

\section{Pendekatan Yuridis yang Digunakan KPPU dalam Perkara Pengadaan Jasa Pembuatan Logo Baru PT. PERTAMINA (Persero)}

Pada kasus praktek diskriminasi dalam pengadaan jasa pembuatan logo baru PT. PERTAMINA (Persero) pendekatan yang digunakanoleh KomisiPengawas Persaingan Usaha (KPPU) dalam mendeteksi dan menganalisis adanya persaingan usaha tidak sehat adalah dengan metode pendekatan" rule of reason". Hal tersebut dapat dilihat pada putusannya, KPPU menilai tindakan tersebut merupakan pelanggaran terhadap ketentuan pasal 19 huruf d Undang-Undang

\footnotetext{
35 Ibid., h. 146.

36 Ibid., h. 149.
}

Nomor 5 Tahun 1999,yang dijabarbarkan unsur-unsurnya antara lain yaitu: pelaku usaha, melakukan praktek diskriminasi terhadap pelaku usaha lain, dan unsur persaingan usaha tidak sehat. ${ }^{37}$

KPPU juga melakukan penilaian berdasarkan pada ada atau tidaknya dampak yang ditimbulkan dari perbuatan yang dilakukan oleh PT. PERTAMINA (Persero) karena praktek diskriminasi dalam pengadaan jasa pembuatan logo baru PT. PERTAMINA (Persero) tersebut terhadap pasar yang bersangkutan. hal ini terlihat dari penilaian hasil analisa KPPU bahwa tindakan diskriminasi tersebut dapat menghambat persaingan karena menutup kesempatan perusahaan pembuat logo lain untuk memberikan jasa pembuatan logo PT. PERTAMINA (Persero). ${ }^{38}$

\section{Penerapan Sanksi Terhadap Pelanggaran} Undang-Undang Nomor 5 Tahun 1999

Dalam dunia usaha dikenal ada etika usaha (business ethic) yang menjadi code of conduct. Meskipun demikian, kekuatan yang mendorong ditaatinya etika semacam itu lebih terletak pada moralitas yang sering terkalahkan oleh kepentingan-kepentingan lain yang dianggap lebih signifikan. UndangUndangnomor5Tahun 1999tentanglarangan praktek monopoli dan persaingan usaha mengintroduksi dua macam jenis sanksi yang dikenakan terhadap pelanggar ketentuan Undang-Undang nomor 5 Tahun 1999. Jenis sanksi yang pertama adalah tindakan administratif, sedangkan jenis sanksi yang kedua adalah sanksi pidana, yang terdiri

\footnotetext{
37 Salinan putusan KPPU,op.cit., h.17-19.

${ }^{38}$ Ibid, h.19.
} 
atas pidana pokok dan pidana tambahan. ${ }^{39}$ Ketentuan mengenai sanksi ini dapat dilihat dalam pasal 47-49 Undang-Undang Nomor 5 tahun 1999. Sanksi yang diberikan dalam UU Undang-Undang nomor 5 Tahun 1999 secara garis besar dapat dibedakan sebagai berikut:

(1) Tindakan administratif sebagaimana yang diatur dalam pasal 47 ayat 2 Undang-Undang No. 5 Tahun 1999;

(2) Sanksi pidana pokok sebagaimana diatur dalam Pasal 48 Undang-Undang No. 5 Tahun 1999;

(3) Sanksi Pidana Tambahan sebagaimana yang diatur dalam Pasal 49 UndangUndang No. 5 Tahun 1999.

Dalam putusannya perkara nomor 13/ KPPU-L/2005 tentang praktek diskriminasi dalam pengadaan jasa pembuatan logo baru PT. PERTAMINA (Persero) pada amar putusanya disebutkan, bahwa :40

1. Menyatakan PT. PERTAMINA (Persero) secara sah dan meyakinkan melanggar Pasal 19 huruf d Undangundang Nomor 5 Tahun 1999 tentang Larangan Praktek Monopoli dan Persaingan Usaha Tidak Sehat karena menunjuk secara langsung LANDOR untuk pembuatan logo PT. PERTAMINA (Persero) tanpa alasan yang sah.

2. Menghukum PT. PERTAMINA (Persero) untuk membayar denda sebesar Rp. 1.000.000.000,- (satu milyar rupiah) yang harus disetorkan

\footnotetext{
39 Arie Siswanto, Op.cit., h.95.

40 Salinan Putusan KPPU, Op.cit., h 19.
}

ke kas Negara sebagai setoran penerimaan negara bukan pajak Departemen Keuangan Direktorat Jenderal Perbendaharaan Kantor Pelayanan Perbendaharaan Negara Jakarta I yang beralamat di Jl. Ir. H. Juanda No. 19 Jakarta Pusat melalui bank pemerintah dengan kode penerimaan 1212 .

Amar putusan KPPU tersebut dapat dilihat bahwa KPPU tidak memberikan sanksi pidana kepada pelaku usaha yang melakukan persaingan usaha tidak sehat, tetapi hanya menerapkan sanksi administratif kepada para pelaku pelanggaran Undang-Undang Nomor 5 Tahun 1999.

Apa yang telah dilakukan oleh KPPU sebagai lembaga pengawas persaingan dalam menerapkan dan menjatuhkan sanksi telah sesuai dengan kewenangan yang diberikan oleh Undang-Undang Nomor 5 Tahun 1999.

\section{Kesimpulan}

1. PT. PERTAMINA (Persero) telah melakukan penunjukan langsung kepada LANDOR dalam kasus pengadaan jasa pembuatan logo baru PT. PERTAMINA (Persero). Proses penunjukan ini bersifat diskriminasi karena PT. PERTAMINA (Persero) menunjuk LANDOR sebagai pengembang tunggal dari proyek pembuatanlogobaruPT.PERTAMINA (Persero) tanpa melalui proses lelang tender serta tidak menghiraukan sama sekali penawaran yang diajukan 
oleh perusahaan- perusahaan lainnya yang sebagai pesaing dari LANDOR. Praktek diskriminasi yang dilakukan PT. PERTAMINA (Persero) menyebabkan penguasaan pasar dan melanggar Pasal 19 huruf d UndangUndang Nomor 5 Tahun 1999 yang di atur secara Rule of reason.

2. Dalam penanganan perkara pengadaan jasa pembuatan logo baru PT. PERTAMINA (Persero), KPPU menggunakan pendekatan yuridis Rule of Reason yang menggunakan teori pembuktian Bright Line Evidence Theory - Diskriminasi yang dilakukan PT. PERTAMINA (Persero) menimbulkan dampak negatif bagi persaingan di bidang jasa pembuatan Logo. Adapun dampak negatif yang timbul akibat praktek diskriminasi yang dilakukan PT. PERTAMINA (Persero) adalah menimbulkan pasar yang bersifat monopoli, LANDOR sebagai penyedia tunggal pembuatan logo PT. PERTAMINA (Persero) akan menjadi pelaku usaha yang memonopoli penyediaan pembuatan LOGO PT. PERTAMINA (Persero), jika hal ini terjadi maka PT. PERTAMINA (Persero) yang berposisi sebagai konsumen jasa pembuatan logo akan sangat dirugikanyang selanjudnyajuga akan merugikan Negara secara tidak langsung, menimbulkan halangan bagi pelaku usaha lain untuk memasuki pasar (barrier to entry), penunjukan langsung oleh PT. PERTAMINA
(Persero) itu akan memberikan hambatan bagi pelaku usaha pesaing LANDOR yang sebernarnya cukup berkompeten untuk masuk kedalam pasar tersebut.

3. Pelaku usaha dalam menjalankan kegiatan usahanya diharapkan dapat mematuhi ketentuan hukum persaingan usaha. Pemerintah sebagai pemilik otoritas tertinggi suatu negara juga harus dapat menghimbau kepada BUMN seperti PT. PERTAMINA (Persero) agar dalam melakukan kegiatan usahanya tidak mengunakan cara-cara diskriminasi yang dilarang oleh Undang-Undang Nomor 5 Tahun 1999.

4. KPPU (Komisi Pengawas Persaingan Usaha) dalam menjatuhkan sanksi kepada para pelaku usaha yang terbukti melakukan praktek diskriminasi jangan hanya berupa penjatuhan denda yang telah terbukti melanggar tetapi juga pemberian sanksi yang lebih tegas, seperti misalnya pembatalan kontrak. Hal ini mengingat dampak negatif yang ditimbulkan dari persaingan usaha yang tidak sehat cukup besar. Pemberian sanksi yang tegas diharapkan dapat memberikan shock therapy kepada para pelaku usaha lainnya, agar tidak kembali melakukan praktek diskriminasi di kemudian hari. 


\section{DAFTAR BACAAN}

ELIPS, Laporan Kebijakan Persaingan Indonesia, Jakarta, 2000.

, Persaingan Usaha Dan Hukum Yang Mengaturnya diIndonesia, Jakarta 2000.

Hansen, Knud, et.al., Law Concerning Prohibition of Monopolistic Practices and Unfair Business Competition, GTZ, Katalis, Jakarta, 2001.

Kagramanto, L. Budi dan Sinar Aju Wulandari, Buku Ajar Hukum Persaingan Usaha, Surabaya, 2005.

Kagramanto, L. Budi, Larangan Persekongkolan Tender : Perspektif Hukum Persaingan Usaha, Cet. I., Srikandi, Surabaya, 2008.

Partnership for Business Competition, Persaingan Usaha dan Hukum yang Mengaturnya di Indonesia, Jakarta, 2001.

Samuelson, Paul A. dan William D. Nordhaus, Ilmu Makro Ekonomi, Media Global Edukasi, Jakarta, 2004

Siswanto, Arie, Hukum Persaingan Usaha, Ghalia Indonesia, Ciawi, 2004.

Sitompul, Asril, Praktek Monopoli dan Persaingan Usaha Tidak Sehat, Citra Aditya Bakti, Bandung, 1999.

Tri Anggraini, A.M., Larangan Praktek Monopoli dan Persaingan Tidak Sehat, cet. I, Program Pasca Sarjana. Fakultas Hukum Universitas Indonesia, Jakarta, 2003
Usman, Rachmadi, Hukum Persaingan Usaha Di Indonesia, Gramedia Pustaka Utama, Jakarta, 2004.

Yani, Ahmad dan Gunawan Widjaja, Seri Hukum Bisnis Anti Monopoli, RajaGrafindo Persada, Jakarta, 1999.

Kagramanto, L. Budi, " Prinsip Per Se Illegal dan Rule of Reason dalam Hukum Persaingan Usaha", Yuridika, Vol.19, No.2, Maret 2004.

Wahyuningtyas, Sih Yuliana, "Urgensi PengaturanTentang Pasar Bersangkutan Dalam Hukum Persaingan Usaha Di Indonesia", Jurnal Hukum Bisnis, Vol. 24, No 2, 2005.

Tri Anggraini, A.M., "Penerapan Pendekatan Rule of Reason dan Per Se Ilegal dalam Hukum Persaingan", Jurnal Hukum Bisnis, Vol. 24, No 2, 2005.

Undang-Undang Nomor 5 Tahun 1999 Tentang Larangan Praktek Monopoli dan Persaingan Usaha Tidak Sehat.

Putusan Perkara Nomor: 02/KPPU-L/2006 Tentang Dugaan Pelanggaran UU Nomor 5 Tahun 1999 Terkait dengan pengadaan jasa pembuatan logo Pertamina. 